\title{
PENGALAMAN KLIEN DENGAN KESURUPAN
}

\author{
Wigyo Susanto*, Dian Oktaviana \\ Fakultas Ilmu Keperawatan, Universitas Islam Sultan Agung Semarang, Jl. Kaligawe Raya No.KM. 4, Terboyo \\ Kulon, Kec. Genuk, Kota Semarang, Jawa Tengah, Indonesia 50112 \\ *orangjiwa@gmail.com
}

\begin{abstract}
ABSTRAK
Banyak diberitakan oleh media masatentang munculnya kasus kesurupan masal atau yang sering dikenal dengan mass dissociative trance disorder, kasus tersebut kerap sekali terjadi pada siswa dan siswi yang sedang mengenyam pendidikan ditingkat SD, SLTP, SLTA, bahkan sampai tingkat Perguruan Tinggi. Munculnya fenomena tersebut tentunya menjadi pertanyaan besar bagi masyarakat luas dan lebih khusus lagi bagi para akademisi, mengapa fenomena tersebut bisa terjadi?, apa yang mereka rasakan sehingga bisa mengalami kesurupan?. Penelitian ini bertujuan untuk mengungkap fenomena kesurupan secara mendalam dengan uangkapan langsung dari individu yang pernah mengalami kesurupan di Universitas Islam Sultan Agung Semarang melalui studi fenomenologi deskriptif, untuk mendapatkan gambaran bagaimana pengalaman seseorang yang pernah mengalami kesurupan. Penelitian studi fenomenologi dengan metode kualitatif, yaitu menggali informasi sedalam-dalamnya tentang pengalaman seseorang yang meliputi sikap, keyakinan, kepercayaan, dan perilaku dari sudut pandang individu tersebut.Analisa menggunakan Georgi. Hasil penelitian mengungkapkan adanya 4 tema penelitian yaitu, definisi kesurupan, penyebab kesurupan, efek kesurupan, cara menyembuhkan kesurupan.
\end{abstract}

Kata kunci : pengalaman, klien, kesurupan

\section{CLIENT EXPERIENCE WITH DISSOCIATIVE TRANCE DISORDER}

\section{ABSTRACT}

Lately there has been a lot of news from the media about the emergence of mass dissociative trance cases, this case often happens to students who are educating at the elementary, junior high, high school, and even to the university level. The emergence of this phenomenon is certainly a big question for the wider community and more specifically for academics, why does this phenomenon occur? What do they feel so that they can experience trance?. This study aims to uncover the phenomenon of possession in depth with direct capture from individuals who have experienced possession at Sultan Agung Islamic University in Semarang through descriptive phenomenological studies, to get a picture of how the experience of someone who has experienced possession. The study of phenomenological studies with qualitative methods, which dig deep information about a person's experience which includes attitudes, beliefs, beliefs, and behavior from the point of view of the individual. The analysis uses Georgi. The results revealed 4 research themes, namely the definition of possession, the cause of possession, possession effect, how to cure possession.

Keywords: experience, clients, possessed

\section{PENDAHULUAN}

Kesurupan atau dissociative trance disorder merupakan masalah hangat yang ditayangkan oleh media televisi dan media koran di Indonesia. Menurut Koran harian kompas terdapat beberapa kasus kesurupan yang terjadi di Indonesia, diantaranya berita harian kompas senin tanggal 23 Februari tahun 2015, puluhan murid Madrasah Tsanawiyah (MTs) di kecamatan Pakisaji, kabupaten Malang Jawa Timur mengalami kesurupan masal saat menggelar api unggun pada acara kemah pramuka. Berita kedua Selasa 17 September 2013, sebanyak 20 siswi dan 1 guru SMK Negeri 1 Kendit, Situbondo Jawa Timur mengalami kesurupan saat akan mengikuti peringatan hari ulang tahun (HUT) kedelapan sekolah mereka. 
Berita ketiga Sabtu 13 Juni 2015, sebanyak 20 siswi Madrasah Aliyah Negeri (MAN 2) Pamekasan Madura Jawa Timur mengalami kesurupan masal saat mengikuti upaca bersama disekolahan mereka. Berita ke empat Kamis 25 April 2013, puluhan mahasiswi Sekolah Tinggi Ilmu Kesehatan (STIKes) Ubudiyah Banda Aceh mengalami kesurupan masal saat sedang menunggu dosen di ruang kuliah lantai dua di kampus mereka. Kasus kesurupan di Negara Indonesia setiap tahun meningkat tajam, pada tahun 2005 sampai tahun 2006 ditemukan ada 20 kasus kesurupan, kemudian ada lebih dari 37 kasus kesurupan yang terjadi di tahun 2007, dan pada awal tahun 2008 ditemukan ada 23 kasus kesurupan yang terjadi di Indonesia (Hidajat, 2008).

Kasus kesurupan, ternyata bukan cuma di Negara Indonesia saja, namun juga terjadi di selururjah dunia, pada tahun 1998 sampai dengan tahun 2010, ada 28 artikel yang melaporkan sebanyak 402 kasus kesurupan yang terjadi di seluruh dunia, sebagian besar kasus tersebut terjadi di Negara Asia, yaitu sebanyak 19 artikel yang melaporkan kasus kesurupan, dari Negara Eropa ada 5 artikel, Amerika 2 artikel, dan dari Negara Afrika ada 2 artikel yang melaporkan kasus kesurupan (During et. Al, 2011).

Proses kesurupan, individu akan mengalami kehilangan sementara aspek penghayatan akan identitas dirinya, dia akan kehilangan kesadaran terhadap lingkungannya, dan dalam beberapa kejadian, individu yang mengalami kesurupan akan berperilaku seperti kepribadian lain, sepertihalnya Malaikat, kekuatan gaib, atau kekuatan lainnya (Diniarti Sri, \& Hanati, 2012). Ciri tersebut, persis seperti kejadian yang pernah peneliti temukan pada saat peneliti menjumpai kasus kesurupan masal pada mahasiswa di Universitas Islam Sultan Agung Semarang.Pada saat itu, terdapat 7 mahasiswi yang mengalami kesurupan.

Peneliti sangat penasaran dengan kejadian tersebut, sehingga peneliti mendekati mereka dan mendengarkan dialog antara salah satu mahasiswi yang sedang mengalami kesurupan (Nn.T) dengan salah satu warga yang sedang berusaha untuk menyadarkannya (Tn.K). Data yang peneliti temukan adalah bahwa $\mathrm{Nn}$. T, mengaku sebagai seorang ustadzah, dia berjenis kelamin perempuan, dan diaakan selalu menjaga Nn. T. dalam kondisi apapun. Pada saat didekati Tn. K, Nn. T menyuruh Tn. $\mathrm{K}$ untuk segera pergi dan tidak mencampuri urusannya.Setelah Nn. T sadar, penelitimendekati Nn. $\mathrm{T}$ dan berdialog dengannya. Data yang didapatkan adalah bahwa Nn. T dalam kondisi sedang menstruasi, dia mengatakan tiba-tiba merasa jengkel dengan ulah teman-temannya yang susah diatur dantidak lama kemudian dia mengalami kesurupan dan mahasiswi yang lain juga ikut mengalami kesurupan sehingga mengakibatkan kepanikan.

Fenomena tersebut, menimbulkan pertanyaan besar dibenak peneliti, sebenarnya apa saja yang dirasakan oleh para mahasiswaselama mereka kesurupan?, berdasarkan latar belakang, maka perlu diadakan penelitian untuk mengungkap fenomena kesurupan secara mendalam dengan uangkapan langsung dari individu yang pernah mengalami kesurupan di Universitas Islam Sultan Agung Semarang melalui studi fenomenologi deskriptif, untuk mendapatkan gambaran bagaimana pengalaman seseorang yang pernah mengalami kesurupan.

\section{METODE}

Metode yang digunakan dalam penelitian ini adalah metode kualitatif, yaitu untuk menggali informasi sedalam-dalamnya tentang pengalaman seseorang yang meliputi sikap, keyakinan, kepercayaan, dan perilaku dari sudut pandang individu tersebut. Analisa data dalam penelitian ini menggunakan analisa Georgi (1998). Penelitian ini telah diuji etik oleh tim etik Fakultas Ilmu Keperawatan Universitas Islam Sultan Agung Semarang dengan nomor 109/A1.S1/FIK-SA/II/2020.

\section{HASIL}

Penelitian ini telah dilakukan di Universitas Islam Sultan Agung Semarang, dengan 5 informan penelitian. Peneliti telah melakukandeep interviewpada bulan Maret 2019 pada 5mahasiswi yang pernah mengalami kesurupan sebagai berikut :

Informan ke 1

"Kesurupan yang saya ketahui adalah akibat dari banyaknya pikiran, masalah yang tidak kunjung padam, dan akibat tidak dekat dengan Tuhan, pikirannya kosong, sehingga mudah ketempelan roh halus. Setelah mengalami kesurupan saya cenderung untuk diam, karena 
takut melihat hal yang begituan lagi. Saya biasanya tersadar setelah dibacain ayat suci Al-Qur;an oleh tetangga saya”.

Informan ke 2

"Kesurupan ya pikiranne kosong, ". kebanyakan masalah, terus anak itu mungkin gampang sekali pikirane kosonng sehingga makhluk lain mudah untuk menguasainya. Terus terang saja saya merasa lebih jadi penakut karena sering melihat makluk goib. Rata-rata setelah dibacain ayat suci Al-Qur'an jin nya pergi dan saya jadi sembuh”.

Informan ke 3

"Mungkin ketempelan makhluk halus njih pak, karna memang diluar kendali saya, tiba-tiba saja saya merasa takut yang luar biasa, dan ujung-ujungnya tidak sadarkan diri, pas ada suara orang ngaji tiba-tiba saja saya bisa terbangun, biasanya saya kalo lagi banyak yang dipikirkan jadi mudah untuk kesurupan".

Informan ke 4

"Pada saat saya kesurupan, saya merasa dikendalikan oleh makhluk halus, tangan dan kaki merasa lemes dan sulit digerakan, tibatiba sudah tidak sadarkan diri. Saya ndak tahu apa yang sedang terjadi, cuman ingetnya pas lagi ada orang ngaji aja”.

Informan ke 5

"Biasa itu pak, kayak ketempelan jin, sebenarnya saya sadar, tapi kenapa ya tidak bisa berbuat apa-apa, badane lemes, mau ngomong susah banget, tapi pasa dibisikin kata-kata penyemangat, saya perlahan jadi sadar".

\section{PEMBAHASAN}

Penelitian ini telah dilakukan di Universitas Islam Sultan Agung Semarang, dengan 5 informan penelitian.Peneliti telah melakukandeep interviewpada bulan Maret 2019 pada 5mahasiswi yang pernah mengalami kesurupan.Hasil penelitian kemudian dianalisis dengan analisis Georgi (1998). Setelah melihat manuskrip data, maka ada beberapa tema yang dapat ditentukan, yaitu : devinisi kesurupan, penyebab kesurupan, cara menyembuhkan kesurupan, dan efek dari kesurupan.

a. Definisi Kesurupan

Informan ke 1,2,3,4,5 semuanya sepakat menyatakan jika Kesurupan merupakan kejadian masuknya mahluk halus pada tubuh seseorang karena fikiran kosong dan banyak masalah.

\section{b. Penyebab Kesurupan}

Tiga dari 5 informan menyampaikan bahwa fikiran kosong dan tekanan psikologis merupakan penyebab terjadinya kesurupan.

c. Efek dari kesurupan

Tiga dari 5 informan menyampaikan jika mereka lebih merasa ketakutan setelah mereka mengalami kesurupan (paranoid).

d. Cara menyembuhkan kesurupan

Empat dari 5 informan menyampaikan jika merukyah dengan ayat suci Al-Qur'an (mendatangi perukyah), dan memperkuat iman merupakan cara paling efektif dalam menyembuhkan kesurupan.

Informan ke 1,2,3,4,5 semuanya sepakat menyatakan jika Kesurupan merupakan kejadian masuknya mahluk halus pada tubuh seseorang karena fikiran kosong dan banyak masalah. Devinisi tersebut sesuai dengan Hastono (2012) yang menyempaikan bahwa kesurupan sering didevinisikan sebagai proses masuknya suatu roh kepada seseorang dan roh tersebut menguasainya. Orang yang mengalami kesurupan seketika itu akan bertingkahlaku menjadi orang lain atau makhluk lain.Pernyataan tersebut juga didukung oleh Van Duijl, Kleijn, \& De Jong, (2013), yang menyampaikan bahwa kesurupan yang terjadi di belahan alam ini, sebagian besar dipengaruhi oleh unsur budaya, unsur spiritual dan unsur kekuatan makhluk lain.

Tiga dari 5 informan menyampaikan bahwa fikiran kosong dan tekanan psikologis merupakan penyebab terjadinya kesurupan. Pendapat tersebut dikuatkan oleh Joyana (2014), yang menyampaikan bahwa kepahitan hidup yang dialami oleh seseorang, seperti halnya mereka yang menjadi korban bencana banjir, korban tsunami, korban ketidakadilan, korban kesenjangan hidup, serta mereka yang mengalami tekanan mental dan tekanan sosial lainnya, semuanya itu disinyalir oleh beberapa psikiater sebagai penyebab terjadinya kesurupan. Selain itu, pendapat tersebut juga dikuatkan oleh Hidajat (2008), yang menyampaikan bahwa umumnya individu yang mengalami kesurupan adalah mereka 
yang berasal dari golongan ekonomi rendah, selain itu masa kecil yang kurang menyenangkan, dan tindakan traumatic akibat kekerasan dimasa kecil juga ikut mempunyai andil terhadap proses terjadinya kesurupan.

Empat dari 5 informan menyampaikan jika merukyah dengan ayat suci Al-Qur'an (mendatangi perukyah), dan memperkuat iman merupakan cara paling efektif dalam menyembuhkan kesurupan. Hal tersebut sesuai dengan ungkapan Chiu,S.N. (2000) yang menyampaikan bahwa masyarakat pedesaan biasanya senang meminta pertolongan ahli agama (ulama) dalam menangani kasus kesurupan.

Tiga dari 5 informan menyampaikan jika mereka lebih merasa ketakutan (paranoid) setelah mereka mengalami kesurupan. Hal tersebut menjadi faktor traumatic experience tersendiri bagi siapa saja yang baru pernah mengalami kesurupan. Sehingga kejadian kesurupan itu bisa terulang lagi (kambuh). Hal tersebut sesuai dengan ungkapan Hidajat (2008), yang menyapaikan bahwa penyebab kesurupan adalah traumatic experience.

\section{SIMPULAN}

Terdapat 5 tema yang dapat disimpulkan, yaitu, definisi kesurupan, penyebab kesurupan, cara menyembuhkan kesurupan, dan efek dari kesurupan.

\section{DAFTAR PUSTAKA}

Chiu, S.N. 2000. Historical, Religious, \& Medical Perspectives of Possession Phenomenon. Hong Kong Journal of psychiatry. 10/1: 14-18.

During, E. H., Elahi, F. M., Taieb, O., Moro, M., \& Baubet, T. (2011). A critical review ofdissociative trance and possession disorders: etiological, diagnostic, therapeutic, andnosological issues. Canadian Journal Of Psychiatry. Revue Canadienne DePsychiatrie, 56(4), 235-242.

Harsono. (2012). Gambaran Trans disosiatif pada mahasiswi.Journal of Social] and IndustrialPsychology.http://journal.unne s.ac.id/sju/index.php/sip,1(4).12-15.

Hidajat, L.L. (2008). Understanding the Mass Trance

Phenomenon
Indonesia:BetweenTraditional Beliefs and Community Mental Health. Anima,Indonesian

PsychologicalJournal. 23/4: 333-337.

Joyanna, Silberg. (2004). Guidelines for the Evaluation and Treatment of Dissociative Symptoms in Children and Adolescents. Journal of Trauma \& Dissociation, Vol. 5(3).23-25.

Maslim, R. (2001). Buku saku diagnosis gangguan jiwa rujukan ringkas dari.1015 PPDGJ-III. Jakarta : Bagian ilmu kedokteran jiwa FK-Unika Atmajaya.

Moleong, L. J. (2011). Metodologi Penelitian Kualitatif . Edisi Revisi. Bandung: PT. Remaja Rosdakarya. 24-30

Polit, D.F., \& Beck, C.T.,(2010).Nursing research: Principles And Methods.7thed,Philadelpia:

J.B.Lippincott.30-40

Pollit, P.F., Beck, C.T., \& Hugler, B.P., (2001). Essential of nursing research: Methodappraisal and utilization. Philadelpia: J.B.Lippincott.40-50.

Rahardanto M.S., \& Subandi.(2012). From Acute Pain to Intense Elation: The PsychologicalDynamics of Five Individuals Who Experienced . Jurnal Psikologi.vulume 39. No. 1juni 2012: 25-45

Steubert H.J., \& Carpenter D.R., (2003). Qualitative Research in nursing: Advancing the humanistic imperative. Philadelpia: J.B. Lippincott

Sugiyono. (2005). Metode penelitian kuantitativ dan kualitativ. Alfabeta : Bandung

Van Duijl, M., Kleijn, W., \& De Jong, J. (2013). Are symptoms of spirit possessed patients covered by the DSM-IV or DSM-5 criteria for possession trance disorder? A mixedmethod explorative study in Uganda. Social Psychiatry and PsychiatricEpidemiology,48(9), 14171430. doi:10.1007/s00127-012-0635-1. 